\title{
The Market Reaction to the Appointment of Women on Corporate Boards: Evidence from the Italian Listed Companies
}

\author{
Patrizia Pastore ${ }^{1}$, Silvia Tommaso ${ }^{1} \&$ Antonio Ricciardi ${ }^{1}$ \\ ${ }^{1}$ Department of Business Administration and Law, University of Calabria, Arcavacata di Rende Cs, Italy \\ Correspondence: Patrizia Pastore, Department of Business Administration and Law, University of Calabria, Cube \\ 3C -Ponte P. Bucci, 87036 Arcavacata di Rende Cs, Italy. E-mail: patrizia.pastore@unical.it
}

Received: September 20, 2017

Accepted: October 30, 2017

Online Published: November 20, 2017

doi:10.5539/ijbm.v12n12p64

URL: https://doi.org/10.5539/ijbm.v12n12p64

\begin{abstract}
Although this study is the result of joint reflections and collaboration, for academic reasons Sections 1, 3, 4 are to be attributed to Patrizia Pastore, Sections 2, 5 are to be attributed to Silvia Tommaso and Section 6 is to be attributed to Antonio Ricciardi.
\end{abstract}

\begin{abstract}
During the 2012-2016 period, a large number of Italian companies appointed women directors in their boards, an unusual and unpredictable fact in the Italian industrial system. This paper investigates if any significant reaction has consequently occurred in the Italian stock market. It assumes that a significant market reaction would indicate the investors view the female board members as a strategic value added at the decision making level. To achieve the objective, it was collected a database consisting of 76 appointments of women directors in 67 Italian listed companies over the period 2012-2016 and then it was investigated the stock price performance of those companies in that five years span. The research hypothesis is examined empirically through the event study methodology in order to check the existence of abnormal returns on the appointment of women directors. Findings suggest that investors do not strongly believe that the simple appointment of women directors would have a positive effect on the future performance of firms.
\end{abstract}

Keywords: Abnormal returns, board composition, corporate boards, event study, female directorship, gender diversity, market reaction, stock price reaction, women on boards

\section{Introduction}

Gender equality on board of directors is quite a hot topic worldwide.

Women scored a markable progress in education and presence in labour market, but they still have to face a large number of difficulties to advance into boardrooms. In fact, they are still under-represented worldwide with wide variations across countries.

Many international studies stated that women directors are able to improve corporate governance (Carter, Simkins, \& Simpson, 2003) and boards' monitoring roles (Zaltman, 1997; Bradshaw \& Wicks, 2000) and influence company's financial and social performances (Erhardt, Werbel, \& Shrader, 2003; Singh, Vinnicombe, \& Johnson, 2001). The relevance of this topic has been well reflected in the political decision of some European countries that have imposed compulsory quotas to promote a broader presence of women in the boardrooms of companies (the leading example: Norway in 2003). At the same time many companies reacted by spontaneously modifying corporate governance rules so to promote gender diversity policies. In Italy, government introduced by law (No.120 of 12 July 2011) the so called "pink quotas" to increase the number of women in the management and supervisory boards of listed companies as well as those majority-owned by a government entity (for which the rule was enforced, respectively, from August 2012 and from February 2013). As a consequence of this law the representation of women in Italian corporate boards has crossed the line of 30\% in year 2016 up from $11.6 \%$ in year 2012. However, progress recorded mainly affects non executive positions: women are independent directors in the $68.6 \%$ of cases. Therefore, the Italian executive women are not strictly related to the company owners. Probably, the presence of women imposed by law cannot be considered the most appropriate choice. But, it constituted a useful break with the past and it could affect positively the future performance of the Italian companies.

Although many studies investigated the relationship between the increased presence of women on the boards and 
companies operational and financial performance (ROA, ROE, ROI, ROS, Tobin's Q), an under-explored field is the stock markets' reactions to women's appointments to the boards (Bonnier \& Bruner, 1988; Charitou, Patis, \& Vlittis, 2010; Dobbin \& Jung, 2011; Dunn, 2012; Fredericks, 2014; Ku Ismail \& Manaf, 2016). To our knowledge, positive abnormal returns have been scored following the appointment of women directors in Singapore (Kang, Din, \& Charoenwong, 2010; Ding \& Charoenwong, 2013) and in Spain (Campbell \& Mínguez-Vera, 2010).

Leaving aside the quantitative growth of female presence on Board of Directors (BODs) as well as the direct relations with the ownership, no studies or empirical researches on market reactions to women being in charge of top positions have been developed in Italy. So, we decided to focus this study on share price movement around the appointment days (21 days span, ten before and ten after the appointment days and the date of the appointment itself). It assumes that a significant market reaction would indicate the investors view the presence of women as a strategic value added, by offering new ideas and different perspectives at the decision making level (Pastore \& Tommaso, 2016).

To achieve the objective, once we collected the useful information in a specific database, it was investigated the stock price performance of 67 Italian listed companies appointing 76 women directors over the period 2012-2016, by using an event study methodology.

At the current evaluation step of the study, we believe that the investors have not been influenced by the gender itself but skills, capabilities and reputation of the new (male or female) directors are the main keys factors, agreeing with the conclusion of $\mathrm{Ku}$ Ismail and Manaf (2016).

The paper is organized as follows. Section 2 presents the hypotheses and the research methodology. Section 3 provides the international literature and empirical studies regarding women's representation in BoDs and its influences on the decision-making process and companies' performances. Section 4 shows the data of improved presence of the women on the Italian corporate boards of the largest publicly listed companies four years after the new Law. Section 5 shows the results of event study. Section 6 is for closing remarks and suggestion for research next steps.

\section{Hypotheses and Research Methodology}

Research main assumption:

\section{H1: Investors react to the appointment of women on boards of directors}

In this paper, the research hypothesis is examined empirically through the event study methodology. Particularly, we used the market model method (Campbell, Lo, \& MacKinlay, 1997; Brown \& Warner, 1980) to check the existence of an abnormal returns on the appointment of women directors.

The sample is composed of firms listed in FTSE Italia All-Share Index (217 firms) covering a five-year period, from 2012 (year of entry into force of Law 120/2011) to 2016. During this period, we identified 76 female director appointments in 67 listed companies. Information about number and gender of people in BODs have been obtained from Consob (the public authority regulating the Italian financial markets); the dates of appointment of women directors have been collected by consulting the press releases issued by the companies. Stock prices and market returns (we considered the Ftse Italia All Share Index) have been retrieved from Datastream.

The market model is based on the assumption of a constant and linear relation between actual stock return $\left(R_{i, t}\right)$ and the return of a market index $\left(R_{m, t}\right)$ :

$$
R_{h t}=\alpha_{l}+\beta_{l} R_{q, t}+a_{\ell t}
$$

where:

$R_{m, t}=$ return of the market (estimated on the basis of Ftse Italia All Share Index) on day $\mathrm{t}$;

$\alpha_{\mathrm{i}}=$ constant component of the stock price for firm i, stable throughout the period;

$\beta_{\mathrm{i}}=$ systematic risk measure of firm $\mathrm{i}$, stable throughout the period;

$\varepsilon_{\mathrm{i}, \mathrm{t}}=$ random error term.

To apply the market model, an estimation window was preliminarily defined: according to Ku Ismail and Manaf (2016) and Kang et al. (2010), the expected returns $E\left(R_{i, t}\right)$ are estimated in an estimation windows covering days -200 to -11 . The appointment day of women directors is fixed to day 0 .

The abnormal return $\left(A R_{i, t}\right)$ from an appointment is the actual return $\left(R_{i, t}\right)$ on the stock price of a firm minus the 
expected return $\mathrm{E}\left(\mathrm{R}_{\mathrm{i}, \mathrm{t}}\right)$ over an event window:

$$
A R_{h_{i}}=R_{h i}-E\left(R_{h}\right)
$$

The abnormal return on a distinct day within the event window (we examine a 21-day event window: from day -10 to day 10) represents the difference between the actual stock return $\left(\mathrm{R}_{\mathrm{i}, \mathrm{t}}\right)$ on that day and the normal/expected return, which is predicted based on two inputs: 1) the typical relationship between the firm's stock and its reference index (expressed by the $\alpha$ and $\beta$ parameters); 2$)$ the actual reference market's return $\left(\mathrm{R}_{\mathrm{m}, \mathrm{t}}\right)$ :

$$
A R_{l: t}=R_{l, t}-\left(\alpha_{l}+\beta_{l} R_{w h t}\right)
$$

Where $\mathrm{t}=-10, \ldots,+10$

Average abnormal return is determined as follow:

$$
A A R_{\tau}=\frac{1}{N} g_{T}=L A R_{1, \tau}
$$

To assess the effects of the newly-appointed female director we add up individual abnormal returns to create a Cumulative Abnormal Return (CAR):

$$
C^{A} A R\left(t_{1}, t_{2}\right)=\sum_{t=t_{1}}^{t_{2}} A R_{l_{1}, \tau}
$$

To test for the significance of average abnormal return and cumulative abnormal returns over the event period, we used three parametric and a non-parametric test statistics:

- Crude Dependence Adjustment Test (Brown \& Warner, 1985) that estimates the standard deviation using the time series of sample mean returns from the estimation period;

- Patell's test (Patell, 1976) where the event period abnormal returns are standardized by the standard deviation of the estimation period abnormal returns;

- Standardized cross-sectional test developed by Boehmer, Musumeci and Poulsen (1991) that incorporates the information from both estimation and the event period;

- $\quad$ Rank test (Corrado, 1989) that considers the combined estimation period and event period as a single set of returns, and assigns a rank based on return to each daily for each firm.

\section{Women on Boards, Companies' Performance and Stock Price Reaction around Appointment of Women} to Bods: A Literature Review

To the best of our knowledge, there is no single theory directly explaining the relationship between women's designation to the boards and company performance, market reaction, and stock returns. However, there are quite a bunch of theoretical and empirical studies on the impact of women on boards on the quality of corporate governance and on how governance devices could influence performance and stock market reaction. Therefore, this section presents a two-stage brief state of the art. First, it reviews some theories and studies on the effect of gender-diversity on corporate governance. Then, in the second part, a brief review of the empirical studies on the link between women on boards, companies' performance and stock price reaction is presented.

Research on corporate board composition attracts great attention as the corporate boards play a pivotal role in defining strategic guidelines and subsequent operational performances of companies (Zahra \& Pearce, 1989; Walsh \& Seward, 1990; O'Neal \& Thomas, 1996; Westphal, 1999; Kang et al., 2010, p. 889). It is cristal clear that all the stakeholders (and particularly private and public investors as well as investment funds) are deeply interested in knowing all the aspects regarding to board structure and compositions, board governance regimes and members' reputations and behavior (Dobbin \& Jung, 2011, p. 817). Several theoretical researches highlight that heterogeneity among the members of BoDs and more gender-diverse boards (by appointing more women directors) is associated with the companies' success and image. A lot of researches focused on gender diversity in BoDs well highlight this interest and they are mainly based on the theoretical frameworks of the Agency Theory, the Resource Dependence Theory and Stakeholder Theory.

Firstly, the Agency Theory suggests that a higher qualified representation of women on corporate boards can contribute to enhance problem solving and improve strategic decision-making processes (Kesner, 1988; Daily, Certo, \& Dalton, 1999; Van der Walt \& Ingley, 2003; Triana, Miller, \& Trezebiatowski, 2014) because the diversity in terms of mentality and different professional and human backgrounds is able to generate a different perspective and a wider spectrum of viewpoints, different ideas, experiences and skill set (Hillman, Cannella, \& Paetzold, 2000; Singh, Terjesen, \& Vinnicombe, 2008) to the board oversight, to the debate and to the decisions 
(Watson, Kumar, \& Michaelsen, 1993; Gilbert, Stead, \& Ivancevich, 1999; Baranchuk \& Dybvig, 2009; Bart \& McQueen, 2013). Moreover, as women on boards are largely outside directors since they are generally excluded from "old-boys clubs" (Jensen \& Meckling, 1976; Yang \& Konrad, 2011), they can increase the independence of the board (Daily et al., 1999) and better represent all the shareholders' interests, by ensuring transparency in corporate governance practices (Van der Walt \& Ingley, 2003; Adams \& Ferreira, 2007, 2009; Terjesen, Sealy, \& Singh, 2009; Nielsen \& Huse, 2010) and exercising to the best their board's monitoring roles (Bradshaw \& Wicks, 2000; Stephenson, 2004; Zaltman, 1997). When these conditions are met, it is possible to observe a positive impact on the whole companies' value-chain (Carter et al., 2003; Nguyen \& Faff, 2006; Ferreira, 2010; Luckerath-Rovers, 2013); shareholder returns (Fama, 1980; Freeman, 1984; Clarkson, 1995; Ntim, 2015), and also an improved stakeholder engagement in sustaining company growth (Balasusbramanian, 2013, p. 21).

Also the Resource Dependence Theory (Pfeffer, 1973; Pfeffer \& Salancik, 1978) bolsters this aspect and confirm with strenght that companies with a more balanced gender composition: improve the quality of corporate governance (and its outcomes) and the functioning of the boards and committees; achieve better results in terms of attendance at board meetings (by reducing the absenteeism rate of male members and leading to the best possible strategic decisions) (Note 1), boost innovation (Nielsen \& Huse, 2010; Østergaard, Timmermans, \& Kristinsson, 2011; Galia \& Zenou, 2012; Diaz-Garcia, Gonzalez-Moreno, \& Saez-Martinez, 2013); provide the company with prestige and legitimacy (Bernardi, Bean, \& Weippert, 2002; Brammer, Millington, \& Pavelin, 2009; Fernandez-Feijoo, Romero, \& Ruiz, 2012; Lückerath-Rovers, 2013) with regard to several groups of stakeholders such as employees (Note 2), customers and investors (reputational effect) that can consequently contribute to better corporate performance. These effects are particularly due to the typically female leadership styles and managerial skills: flexibility, attention to people, ability to manage relationships, negotiation skills and conflict management within the organization - encouraging feedback and dialogue, willingness to share power and decision-making, collaborative leadership style, tendency to give others responsibilities, a greater risk-aversion (Rosener, 1997; Adams, Hermalin, \& Weisbach, 2008). The companies that meet these conditions could boost corporate reputation and both financial and social performances (Francoeur, Labelle, \& Sinclair-Desgagne, 2008; Boulouta, 2013; Solakoglu, 2013). Some studies highlight that markets, by considering women as an element of good governance, reward the companies that appoint women on their boards with a higher market valuation, a lower market risk (Olson \& Currie, 1992; N. Smith, V. Smith, \& Verner, 2006) and a lower cost of capital (Gul, Min, \& Srinihdi, 2010). Other significant researches reported a positive association between the visible presence of women in boardrooms and social performance indicators of the organization (Siciliano, 1996; Singh et al., 2001; Miller \& Triana, 2009; Huse, Hoskisson, Zattoni, \& Viganò, 2011), which in turn attain profitability and superior financial performance (Waddock \& Graves, 1997). In terms of social performance, Bear, Rahman and Post (2010) and Boulouta (2013) have found a positive effect on corporate social responsibility: some of firms with higher percentage of women on BoDs are in the (Fortune 500) "World's Most Ethical Companies' list”.

The Stakeholder Theory (Freeman, 1984; Clarkson, 1995) stated that commercial and financial success of a company could also depend on appreciating and focusing on stakeholders' communities interests. Based on that, companies' capacity to develop and maintain positive multiple relationships is a strategic key success factor. Women on boards are generally more stakeholder oriented than male directors and, consequently, they can improve stakeholder relationships (Hillman, Keim, \& Luce, 2001). Therefore, the presence of women is essential. Firstly of all, it would raise the confidence of investors, by guaranteeing transparency and ethical conduct, with as strong benefit on social responsiveness (Arfken, Bellar, \& Helms, 2004). Secondly, it would allow beneficial relationships with a broad stakeholder base, even if stakeholders have different and conflicting sentiments and demands (Freeman, 1984; Donaldson \& Preston, 1995). In this respect, women are more able to handle conflicts of interests and to solve problems (D.A. Brown, D.L. Brown, \& Anastasopoulos, 2002); they are very skilled at dealing with complexity and strategic change (Haynes \& Hillman, 2010; Nielsen \& Huse, 2010) and have a strong orientation towards maintaining and strengthening relationships (Rosener, 1997) and excel in performing collaborative works (Ku Ismail \& Manaf, 2016, p. 78).

The effects of (rising) female participation in the boards on corporate economic and financial performance are yet not well understood. The empirical evidence suggests inconclusive results. The review of the literature suggests that gender diversity in corporate boards by naming more women directors leads to changes in the efficacy or monitoring capabilities of boards. According to Dobbin and Jung (2011, p. 836), "these changes are expected to affect profits directly and stock performance indirectly". Several empirical studies suggest that companies with more women on boards achieve greater profitability and higher stock market values (Smith et al., 2006; Carter, D’Souza, Simkins, \& Simpson, 2010; Erhardt et al., 2003; Catalyst, 2007; Hoogendoorn, 
Oosterbeek, \& Van Praag, 2013). Other empirical studies, on the other hand, reveal that women on boards are associated with modest (Ujunwa, 2012; Dale-Olsen, Schøne, \& Verner, 2013) or even negative accounting performance and lower market valuation (Shrader, Blackburn, \& Iles, 1997; Carter et al., 2003, 2010; Farrell \& Hersch, 2005; Westphal \& Bednar, 2005; Rose, 2007; Hillman, Shropshire, \& Cannella, 2007).

\subsection{The Appointment of Women on Boards and Company Performance}

Several empirical studies reveal positive firm performance in companies where more women have been appointed. Some studies, using Tobin's Q and other performance indicators (ROA, ROE, ROI and ROS), give strong evidence that more women on board would generate enhanced company value (Note 3 ). Whereas other studies yield opposite results revealing a negative association between women on boards and company performance (Van der Walt \& Ingley, 2003; Van der Walt, Ingley, Shergill, \& Townsend, 2006; Rose, 2007; Francoeur et al., 2008; Campbell \& Minguez-Vera, 2008) (Note 4). This evidence would suggest that in many cases women are appointed for "cosmetic" reasons and that tokenism is quite widespread (Huse, 2007). For instance, Huse and Solberg (2006) found that the contribution of women directors in Scandinavia depends on the women directors' ability and willingness to make alliances with influential board members and take leadership roles, among other factors.

\subsection{The Appointment of Women on Boards and Market Reactions}

Normally, investors rely on data and official papers provided by the companies to make investment decisions (Kang, 2008; Sanders \& Boivie, 2004). By adopting a diverse perspective linking board diversity to company performance, some studies have examined the market reactions to the appointment of women to the boards. Generally, the selection (and succession) and the appointment of members of a board of directors (as well as the chief executive officer) are important events for any company and create performance improvements fulfilling the expectations as a result, as directors have a key role in determining company's strategies and performances. In an efficient market (Fama, 1970), stock price performance is a potential source of useful information on mangers' and directors' efficiency (Warner, Watts, \& Wruck, 1988, p. 462). As such, shareholders and investors view the appointment of the members of the boards as a signal for the company's future success or future failure (Denis \& Denis, 1995; Davidson, Nemec, Worrel, \& Lin, 2002; Friedman \& Singh, 1989). Similarly, as women on boards have become one feature of effective governance, and corporate governance is a reliable signal for investors facing asymmetric information (Ajina \& Lakhal, 2010; Karmani, Ajina, \& Boussaada, 2015; Sougné, Ajina, \& Lakhal, 2015), the appointment of women to the boards is viewed as a positive signal as investors believe women directors would bring future prospect to firms. In this perspective, stock price reaction at announcement of a woman appointed could indicate whether the capital market considers the event significant (Warner et al,. 1988, p. 466).

However, the stock market reaction to the appointment of CEOs or board members is an open empirical question (Charitou et al., 2010, p. 273). There is considerable research exploring the relationship between management succession events (and their announcements) and reactions by the stock market (Lubatkin \& Shrieves, 1986; Beatty \& Zajac, 1987; Worrell \& Davidson, 1987). Some studies have examined market reactions to the appointment of women to the corporate boards providing (in this case as well) mixed results.

First of all, in the main (Fortune) 500 US firms, Catalyst in 2004 found that companies with a high representation of women top executives score higher returns on equity and returns to shareholders compared to similar companies with a lower representation. Likewise, positive market reactions to the appointment of women as directors were observed in Spain (Campbell \& Mínguez-Vera, 2010), in Singapore (Ding \& Charoenwong, 2013) and in Malaysia where, particularly, Ku Ismail and Manaf (2016) observed how women's attributes and the role they play in monitoring affect company value (Note 5).

Conversely, other empirical studies found negative correlation between female appointment to the boards and stock price, as in the study by Farrell and Hersch (2005) regarding large U.S. firms during the 1990s. Haslam, Ryan, Kulich, Trojanowski and Atkins (2010), using British data for FTSE 100 companies, suggested that women on corporate boards have negative effects on stock price but not on profitability. In this regard, Lee and James (2007), using a sample of top executive announcements from 1990 to 2000, found that investor reactions to the appointments of female CEOs are significantly negative compared with the positive effects when women are appointed to non-CEO positions (and more negative than those of their male counterparts). Furthermore, women who have been promoted from within a firm are viewed more positively than women who come from outside.

Following the example of these studies, this paper assumes that if stock markets react to a CEO or board member appointment, there could be a possible gender effect in the stock market reactions to the appointment of women 
directors. Thus, it hypothesizes the following

\section{H1: Investors react to the appointment of women on boards of directors}

\section{Women's Participation in Boardrooms of Italian Listed Companies in 2016}

This section of the paper describes female presence on corporate boards of Italian companies listed on the Mta Stock Exchange organized and managed by Borsa Italiana Spa (excluding companies in liquidation) over the period 2012-2016 (that is, four years after Law 120/2011). We collected a large amount of data by using the Reports on corporate governance of Italian listed companies published by Consob.

Overall results are quite encouraging. Indeed, by analysing the companies that have appointed the board of directors after the 2012 Law, you can note that $100 \%$ of listed companies fullfilled the conditions and the principles of gender equality. But, not every Italian firm has implemented the new rules of the law, some of them voluntarily not introducing women on boards, when renewing while others still with the former board.

By looking at the figures, the presence of women on BoDs of listed companies (and their weight on these) has risen dramatically. As compared to the 2012 records (on the eve of the adoption of compulsory quotas), the percentage of directorships held by women has nearly tripled, from $11.6 \%$ to $30.5 \%$ (Consob, 2016, p. 24) while almost every company changed its board, up to $99.0 \%$ of the total, compared to $67.0 \%$ in 2012 (Table 1).

Table 1. Female representation on corporate boards of Italian listed companies

\begin{tabular}{|c|c|c|c|c|c|}
\hline \multirow[b]{2}{*}{ Year } & \multirow{2}{*}{$\begin{array}{c}\text { Listed } \\
\text { companies } \\
\text { no. }\end{array}$} & \multicolumn{2}{|c|}{$\begin{array}{c}\text { Listed companies where at least one female director } \\
\text { sits on the board } \\
\text { (Diverse-board companies) }\end{array}$} & \multicolumn{2}{|c|}{$\begin{array}{l}\text { Board seats held by women } \\
\text { (Female directorship) }\end{array}$} \\
\hline & & no. & $\begin{array}{c}\text { Weight on total } \\
\text { number of board seats }\end{array}$ & no. & $\begin{array}{c}\text { Weight on total number } \\
\text { of listed companies }\end{array}$ \\
\hline 2012 & 251 & 169 & 66.8 & 288 & 11.6 \\
\hline 2013 & 244 & 202 & 83.5 & 421 & 17.8 \\
\hline 2014 & 238 & 217 & 91.9 & 521 & 22.7 \\
\hline 2015 & 234 & 230 & 98.3 & 622 & 27.6 \\
\hline 2016 & 230 & 228 & 99.1 & 687 & 30.3 \\
\hline
\end{tabular}

Source: Our elaborations on Consob data (Report on corporate governance of Italian listed companies, several years).

These data are quite symptomatic of a great cultural change in Italy. Law 120/2011 makes mandatory gender quotas for the three board appointments subsequent to August 2012 by requiring that the members of the under-represented gender shall account for at least one-third of the board (one-fifth for the first term). The male/female mix has changed and now is obviously more balanced in the companies that changed boards after the Law. At the end of June 2016 (Figure 1):

a) in the 140 companies (60\% of market value) that underwent the first board appointment (under the new law) women hold on average 2.6 board seats and account for $27.0 \%$ of the directors;

b) in the 68 companies (32.0\% of market value), which are at the second term in applying the one-third gender quota, women hold on average 3.8 board seats and account for $37.0 \%$ of the directors;

c) in the 8 companies ( $1.5 \%$ of market value) that have already enacted the third term count 3.3 women holding a board seat and account for $35.4 \%$ of total board size;

d) in the 14 companies (6.7\% of market value) that have not applied Law 120/2011 yet, women hold, on average, 2.5 board seats and account for $28.0 \%$ of total board size: the majority of these companies are newly-listed and will apply gender quotas in the three board appointments subsequent to listing. 


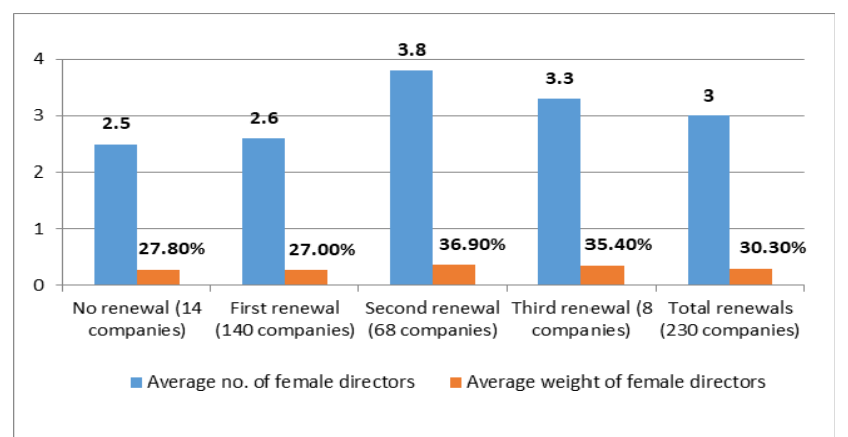

Figure 1. Boards renewals and female representation on corporate boards after the application of Law 120/2011 Source: Our elaborations on Consob 2017.

Overall, boards have on average three female directors, but a certain degree of variation can be observed across industries vertical sectors. In this regard, in the financial companies women hold a larger representativeness both in terms of number of directorship (women cover on average 3.5 board seats) and in terms of weight (over 31\%). This data is slightly higher than to 2.8 and 3.0 seats in industrial and utilities companies, respectively (Table 2).

Table 2. Female representation on corporate boards of Italian listed companies by industry (2016)

\begin{tabular}{|c|c|c|cc|c|} 
& \multicolumn{3}{|c|}{ Diverse-board companies ${ }^{1}$} & \multicolumn{3}{c|}{ Average weight of women on boards } \\
\hline & $\begin{array}{c}\text { LISted } \\
\text { companies no. }\end{array}$ & $\begin{array}{c}\text { \% } \\
\text { market cap }{ }^{2}\end{array}$ & $\begin{array}{c}\text { Average no. of } \\
\text { female directors }\end{array}$ & $\begin{array}{c}\text { In all IIsted } \\
\text { companies }\end{array}$ & $\begin{array}{c}\text { In diverse-Doard } \\
\text { companies }^{1}\end{array}$ \\
\hline Financial & 54 & 100.0 & 3.5 & 31.4 & 31.4 \\
\hline Industrial & 124 & 99.3 & 2.8 & 29.6 & 29.9 \\
\hline Services & 50 & 100.0 & 3.0 & 30.6 & 31.2 \\
\hline Total & $\mathbf{2 0}$ & 99.7 & 3.0 & 30.3 & 30.5 \\
\hline
\end{tabular}

${ }^{1}$ Diverse-hoard companies are firms where at least one female director sits on the hoard

${ }^{2}$ Market value of ordinary shares of companies in each group in percentage of market value of ordinary shares of all companies included in each industry $i$ in each market index.

Companies both in the Star and in the Mid Cap indexes are included only in the Star category

Source: Consob, 2017:32.

Regarding the role in the company, did not occur significant changes, with women not yet in charge of apical positions and still seating in boards as independent directors. At June of 2016, 3.2\% of women on boards are CEO in only 17 companies, that account for a mere $1.7 \%$ of total market capitalization, while over two-thirds of female directors (471) are independent board members in 205 companies (accounting for 98.0\% of total market value). Women appointed chairwoman or honorary chairwoman risen up from $2.5 \%$ in 2005 to $3.1 \%$ in 2016 . That happened in 31 companies accounting for almost a third of the total capitalization of the market. There is still a good presence of women in charge as deputy chairwoman in other 37 firms $(8.8 \%$ in terms of value of the market) while they are decreasing in number when serving as executive directors (5.8\% vs 8.1\% in 2013).

The trend of women on boards serving as independent directors continue furthermore to rise constantly. Their number has increased substantially in size: from 244 women in 2013 to 424 in 2015 up to 471 women at the end of June 2016. Indeed, they have been increasing weight on the board from $59.8 \%$ in 2013 to $68.6 \%$ in 2016 . Over the same period, in 38 large companies (accounting for $62 \%$ of total market capitalization), through the slate voting mechanism, the number of minority female directors doubled from 20 in 2013 (equal to $4.9 \%$ ) to 49 women in June 2016 (equal to 7.1\%). Moreover, in spite of a marked reduction in the interlocking by Italian directors in the last 4 years span, the presence of women in charge of multiple directorships has dramatically increased: currently, 30\% of women directors are interlockers, up from 18\% in 2013 (Table 3). 
Table 3. Positions held by female directors in Italian listed companies*

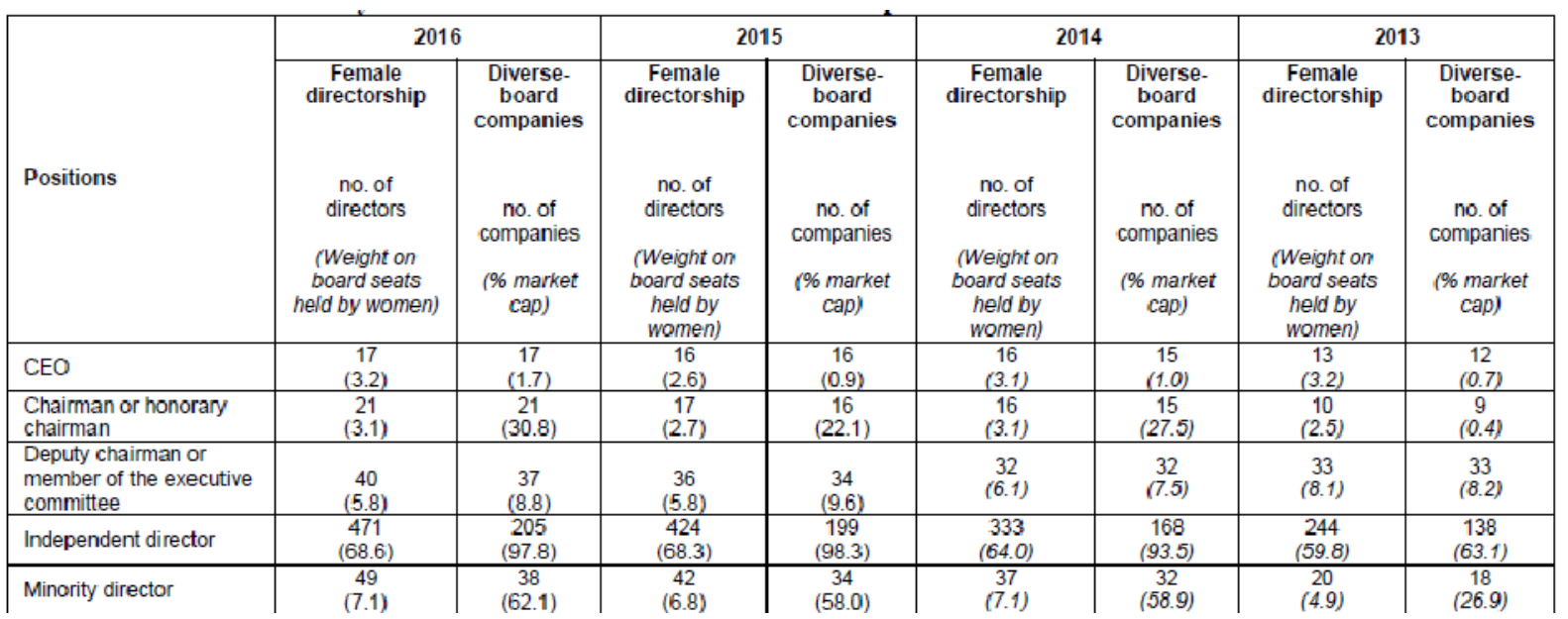

* Data on female directorships have been elaborated by Consob only from the 2013.

Source: Our elaborations on Consob data (Report on corporate governance of Italian listed companies, several years)

Some changes were observed in such parameters as age, degree of education, direct relations with controlling shareholders, and assiduous presence in the board meeting, mainly in comparison to male newly nominee colleagues, so giving an impression of better quality governance. To this respect, based on data by Consob available up to the end of 2015, female directors appointed after 2012 (Table 4):

a) are appreciably younger than male members (about 51 versus 59 years old) so to lower the average age of directors;

b) have a higher profile in terms of education: $88.5 \%$ of them have a first degree ( $84.5 \%$ for males $)$ and $29.7 \%$ have a post-graduate degree ( $16.7 \%$ for males);

c) as for the professional background (with the percentage of managers declining from about 76.0 to $70.0 \%$ and the proportion of consultant/professional rising from around 15 to $21 \%$ ), the newly-appointed female directors are predominantly professionals or consultants $(33.2 \%$ versus $16.6 \%)$ and academics $(12.2 \%$ versus $6.4 \%)$, the proportion of female managers being residual (54.1\% versus $76.5 \%$ for newly-appointed male directors).

The quota system, in other words, has not only increased the number of executive women but has produced a series of positive effects regarding the selection of directors, as companies replaced lower-skilled men with more competent women. Better qualified people presumably will act more effectively and may push and determine better operational and financial results.

Table 4. Directors' attributes in Italian listed companies by gender and tenure

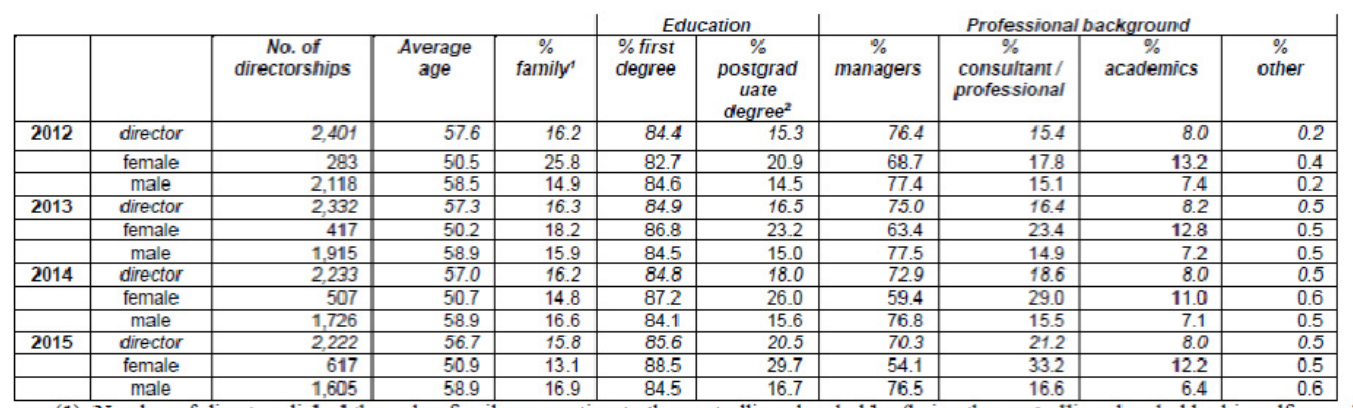

(1) Number of directors linked through a family connection to the controlling shareholder (being the controlling shareholder himself or a close relative) in percentage of the total number of directors included in each category.

(2) Number of graduated directors who attended a postgraduate course and/or hold a $\mathrm{PhD}$ in percentage of the total number of graduated directors in each category.

Source: Our elaborations on Consob 2017. 
Another remarkable change in a country like Italy, where medium and small firms are predominant, quite often controlled and managed by just one family, is that new women in the board do not present quite evident links to the owning family or to controlling investment fund.

Finally, whereas the boards of directors are stronger in numbers, women have a better chance to sit on it.

Another interesting aspect is related to board meeting attendance. The data for 2015 by Consob, which are the most recent available, certify that directors overall attend on average $91.4 \%$ of board meetings (Consob, 2017, $\mathrm{p}$. 31 ), with attendance being lower in private firms $(88.4 \%)$ while hitting its maximum value in State controlled companies $(97 \%)$.

Female board members attend on average $90.0 \%$ of board meetings versus $92.0 \%$ of the male, but the newly-appointed female directors and non-family women show an higher attendance rates than others women. Indeed if you consider index such as participation in boards' meetings, you can track a higher ratio for independent women members $(90.7 \%$ vs $88.9 \%$ of women with links to the owning family) while male members scoring on the contrary more similar ratios (Table 5).

Table 5. Directors' attribute and board meeting attendance in Italian listed companies by gender and relationship with the controlling shareholder (end of 2015)

\begin{tabular}{|c|c|c|c|c|c|c|c|c|c|}
\hline \multicolumn{4}{|c|}{$=$} & \multicolumn{2}{|c|}{ Education ' } & \multicolumn{4}{|c|}{ Professional background } \\
\hline & & $\begin{array}{c}\text { No. of } \\
\text { director } \\
\text { ships }\end{array}$ & $\begin{array}{c}\text { Average } \\
\text { attendanc } \\
e^{y}\end{array}$ & $\begin{array}{l}\% \text { first } \\
\text { degree }\end{array}$ & $\begin{array}{c}\% \\
\text { posigrad } \\
\text { uate } \\
\text { degree }^{2}\end{array}$ & $\begin{array}{c}\% \\
\text { managers }\end{array}$ & $\begin{array}{c}\% \\
\text { consultant/ } \\
\text { professional }\end{array}$ & $\begin{array}{c}\% \\
\text { academics }\end{array}$ & $\begin{array}{c}\% \\
\text { other }\end{array}$ \\
\hline Director & Family $^{3}$ & 352 & 91.3 & 70.5 & 14.9 & 93.8 & 6.3 & - & - \\
\hline & non-family & 1,870 & 91.5 & 88.4 & 21.3 & 65.9 & 24.0 & 9.5 & 0.6 \\
\hline Female & Family & 81 & 88.9 & 64.2 & 19.2 & 84.0 & 16.0 & - & - \\
\hline & non-family & 536 & 90.7 & 92.2 & 30.8 & 49.6 & 35.8 & 14.0 & 0.6 \\
\hline Male & Family ${ }^{3}$ & 271 & 92.0 & 72.3 & 13.8 & 96.7 & 3.3 & - & 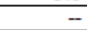 \\
\hline & non-family & 1,334 & 91.8 & 87.0 & 17.2 & 72.4 & 19.3 & 7.6 & 0.7 \\
\hline
\end{tabular}

(1) Average percentage of board meetings attended by the directors included in each category (directors appointed during the year who have been in charge for less than 200 days are excluded)

(2) Number of graduated directors who attended a postgraduate course and/or hold a $\mathrm{PhD}$ in percentage of the total number of graduated directors in each category.

(3) The director is either a family member of the controlling shareholder or is the controlling shareholder

Source: Consob, 2017, p.34.

Literature shows that bringing on board women, even if induced by law, has ultimately positive effects on governance and could also put in place better conditions for financial performances. On the other hand, it is also to take in account that the compelled appointment of women on boards is not a guarantee of success: it is necessary that companies are able to attract and select talented and/or experienced women so to improve BoDs quality.

If the ultimate goal is to provide and deploy optimal governance in a company, the rule number one is to consider merit and skills, avoiding to appoint women only for cosmetics reasons (such as tokens: Kanter, 1977). Otherwise, as well documented by Matsa and Miller (2013), the risk is to reply the Norvegian experience, when companies were forced by law to pull in inexperienced and lower skilled women, by producing in this way some serious damages to the companies' performances.

In Italy, this risk is also clear because family-controlled companies are predominant, whereas the tendency to be complaint to the law could override the real need to find women with the right and most appropriate managerial skills. As a consequence, appointing women in the boards can be really effective and contribute to the success, if companies have in advance adopted and deployed the right policies at any level to recruit, encourage and promote gender equivalence, as well as comparisons of remunerations, and ensuring at the same time a greater transparency of these policies.

\section{Results of the Event Study}

Table 6 shows the average abnormal returns (AAR) and the cumulative average abnormal returns (CAAR) over 21 days of event window from day -10 to day 10 . Negative AARs are observed from day -10 to day -5 and on days $-3,-1,0,2,3$ and 7 . On day 3 , the AAR of $-0.45 \%$ is significant (at the $5 \%$ level using Patell's test, standardized cross sectional test and non-parametric test), whereby 46 firms (60.5\%) react negatively and 30 firms (39.5\%) react positively. Positive AARs are observed on day 1 and from day 4 to 10 (except day 7). Positive AAR (+4\%) is significant on day 9 when 43 firms (56.6\%) react positively and 33 firms (43.4\%) react 
negatively.

Table 6. Average Abnormal Return (AAR) and Cumulative Average Abnormal Return (CAAR) during the event period $(-10,10)$

\begin{tabular}{|c|c|c|c|c|c|c|c|c|}
\hline Day & AAR & $\begin{array}{c}\text { Crude } \\
\text { Dependence } \\
\text { Adjustment } \\
\text { Test }\end{array}$ & Patell's test & $\begin{array}{c}\text { Standardized } \\
\text { cross-sectional } \\
\text { test }\end{array}$ & Rank test & CAAR & Positive & Negative \\
\hline-10 & -0.0021 & -0.8621 & -0.5799 & -0.5526 & -0.9963 & -0.0021 & 33 & 43 \\
\hline-9 & -0.003 & -1.2723 & -1.0807 & -1.3195 & -0.9321 & -0.0051 & 35 & 41 \\
\hline-8 & -0.0004 & -0.1845 & -0.4136 & -0.4237 & -0.0903 & -0.0055 & 40 & 36 \\
\hline-7 & -0.0006 & -0.2557 & -0.2159 & -0.2335 & 0.4313 & -0.0061 & 37 & 39 \\
\hline-6 & -0.0034 & -1.4335 & -1.5744 & $-1.9107^{*}$ & -1.0596 & -0.0095 & 38 & 38 \\
\hline-5 & -0.0021 & -0.8949 & -0.9128 & -0.9306 & -0.5884 & -0.0116 & 35 & 41 \\
\hline-4 & 0.0028 & 1.1703 & 1.0481 & 1.5909 & $1.7478^{*}$ & -0.0088 & 50 & 26 \\
\hline-3 & -0.0011 & -0.471 & -0.0433 & -0.0433 & -0.1111 & -0.0099 & 37 & 39 \\
\hline-2 & 0.0032 & 1.3367 & 0.6113 & 0.522 & 0.1111 & -0.0067 & 38 & 38 \\
\hline-1 & -0.0017 & -0.7309 & -0.8146 & -0.7865 & -1.2792 & -0.0084 & 30 & 46 \\
\hline 0 & -0.0021 & -0.8663 & -1.3713 & -1.247 & -1.3347 & -0.0105 & 33 & 43 \\
\hline 1 & 0.0019 & 0.7807 & 0.8785 & 1.1115 & 1.1247 & -0.0086 & 41 & 35 \\
\hline 2 & -0.0013 & -0.555 & -0.7712 & -1.2221 & -0.1397 & -0.0099 & 34 & 42 \\
\hline 3 & -0.0045 & $-1.9033^{*}$ & $-2.067 * *$ & $-2.2487 * *$ & $-2.049 * *$ & -0.0144 & 30 & 46 \\
\hline 4 & 0.0017 & 0.7189 & 1.0885 & 1.2061 & 1.3616 & -0.0127 & 39 & 37 \\
\hline 5 & 0.0026 & 1.1081 & 1.1924 & 1.5327 & 1.333 & -0.0101 & 42 & 34 \\
\hline 6 & 0.0001 & 0.0468 & 0.2014 & 0.2131 & -0.066 & -0.0100 & 37 & 39 \\
\hline 7 & -0.0006 & -0.2413 & -0.2655 & -0.2586 & 0.184 & -0.0106 & 39 & 37 \\
\hline 8 & 0.0006 & 0.2611 & 0.3552 & 0.2933 & 0.3784 & -0.0100 & 41 & 35 \\
\hline 9 & 0.004 & $1.6864 *$ & $2.1461 * *$ & $2.0399 * *$ & $1.9822 * *$ & -0.0060 & 43 & 33 \\
\hline 10 & 0.0027 & 1.1316 & $1.6807^{*}$ & 1.3281 & 0.8783 & -0.0033 & 40 & 36 \\
\hline
\end{tabular}

*Significant at the $10 \%$ level.

** Significant at the $5 \%$ level.

Table 7 presents CAARs of various windows. The CAAR's plot is displayed in the Figure 2.

The CAARs were negative all the way and decrease from $-0.21 \%$ on day -10 to $-0.33 \%$ on day 10 . The CAARs are negative and statistically significant over the periods $(-1.3),(2.3)$; the CAARs are positive and statistically significant over the period (4.6), (4.10) and (5.10). Our results are partially in line with those of Abdullah, Ku Ismail and Nachum (2016): they found that women representation on boards are associated with lower Tobin's Q and it suggests that women are less likely to be accepted by investors.

However, in the days following the appointments (from the fourth day onward) markets react positively and 
these findings are consistent with those of $\mathrm{Ku}$ Ismail and Manaf (2016), Campbell and Mínguez-Vera (2008, 2010), Ding and Charoenwong (2013). In these three studies, positive market reactions are reported during the event period.

In the study of Ding and Charoenwong, which concerns companies listed on the Singapore Stock Exchange, is reported an AAR of $1.83 \%$ on the day the announcement is made, with $67.6 \%$ of the companies reported positive abnormal returns. The CAAR also increases, from $0.42 \%$ on day -5 to $1.08 \%$ on day 10 .

The research of Campbell and Mínguez-Vera shows the Spanish market reacted even earlier (day -2$)$ with an AAR of $0.67 \%$. However, according with our results, Campbell and Mínguez-Vera show that the CAARs were negative all the way, from $-0.20 \%$ on day -10 to $-1.17 \%$ on day 10 .

The research of $\mathrm{Ku}$ Ismail and Manaf concerns the Malaysian firms and shows that the market anticipated the appointment of women directors one day prior to the announcement and react positively: on day -1 the AAR increases of $0.90 \%$ with $57.5 \%$ of firms that react positively.

Table 7. Cumulative Average Abnormal Return (CAAR) for various windows

\begin{tabular}{|c|c|c|c|c|c|c|c|}
\hline Days & CAAR & $\begin{array}{c}\text { Crude Dependence } \\
\text { Adjustment Test }\end{array}$ & Patell's test & $\begin{array}{c}\text { Standardized } \\
\text { cross-sectional } \\
\text { test }\end{array}$ & Rank test & Positive & Negative \\
\hline$(-10 \ldots 10)$ & -0.0034 & -0.3121 & -0.1981 & -0.2079 & 0.1934 & 42 & 34 \\
\hline$(-10 \ldots 7)$ & -0.0107 & -1.0628 & -1.1997 & -1.3242 & -0.5545 & 35 & 41 \\
\hline$(-7 \ldots 7)$ & -0.0052 & -0.5655 & -0.7787 & -0.8794 & -0.0863 & 34 & 42 \\
\hline$(-1 \ldots 3)$ & -0.0078 & -1.4645 & $-1.854^{*}$ & $-2.1375^{* *}$ & -1.6448 & 30 & 46 \\
\hline$(0 \ldots 1)$ & -0.0002 & -0.0605 & -0.3485 & -0.3607 & -0.1485 & 40 & 36 \\
\hline$(2 \ldots 3)$ & -0.0058 & $-1.7383^{*}$ & $-2.0069 * *$ & $-2.4883 * *$ & -1.5476 & 32 & 44 \\
\hline$(4 \ldots 6)$ & 0.0045 & 1.0818 & 1.4332 & $1.8699 * *$ & 1.5177 & 43 & 33 \\
\hline$(4 \ldots 10)$ & 0.0112 & $1.7808^{*}$ & $2.4186^{* *}$ & $2.5207 * *$ & $2.2872 * *$ & 44 & 32 \\
\hline$(5 \ldots 10)$ & 0.0095 & 1.63 & $2.168 * *$ & $2.2192 * *$ & $1.9146^{*}$ & 48 & 28 \\
\hline
\end{tabular}

*Significant at the $10 \%$ level.

** Significant at the $5 \%$ level.

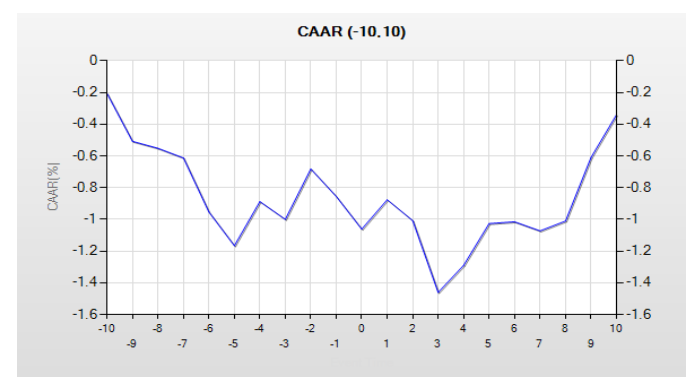

Figure 2. Cumulative Average Abnormal Return (CAAR) from day -10 to day 10.

Source: Our Elaboration.

Definitely, our results show not significant effects on the days prior to the appointment; a positive significant effect on day 9; a negative significant effect on day 3. This suggests that investors do not believe that the simple appointment of women directors would have a positive effect on the future performance of firms. Rather, we think the characteristics of the (male or female) directors could determine the company's performance and thus 
influence the stock returns.

In the research development, in addition to investigating all cases of new female appointments in the 2012-2016 period, we intend to verify whether there is a relationship between the stock returns and the attributes of the women appointed on the board of directors. These attributes may include: international experience; education; family relationship; multiple directorship.

\section{Conclusions}

It is still too early to draw final conclusions on these issues.

Based on the available literature there are no conclusive results on a specific direct link between appointing women on boards and improved financial as well as business performances of the companies.

No proven results emerge also from our study, where we adopted a different point of view, by explaining the market reaction immediately previous to and following the appointments of women on Italian corporate boards. At the moment, we have investigated only 76 cases of new female appointments and our results suggest that investors do not believe that the simple appointment of women directors would have a positive effect on the future performance of firms. However, the small number of cases investigated represents the limit of the study so we intend to investigate all cases of new female appointments in the 2012-2016 period to verify, in a more reliable manner, the market reactions to the appointment of women to the board of Italian firms.

We expect that further developments of this study could greatly support the organizations and capital market participants, such as investors, analysts, bankers, in putting more emphasis on the selection criteria of the board member appointment, and subsequently in generating shareholders' wealth. Indeed, any positive relationship between appointment of women on Italian corporate boards and stock price could likely indicate that society appreciates gender diversity in the boardroom, if companies appoint qualified women as members, and reflect a legitimacy effect in which shareholders are positively disposed toward the companies for complying with regulations. Furthermore, the results of this study could allow conclusions to be drawn about the opportuneness of the policy of having women representation on boards. In this regard, the gender quotas imposed by legislation could have negative effects, such as to involve women on the boards with less experience, without the appropriate expertise and qualifications required for membership to the board (in order to enforce the law) and exclude those able to affect positively the quality of board governance. In this case women could suffer less credibility within boards and their opinions could be more likely to be ignored or marginalized (Westphal \& Milton, 2000) making their influence almost null on decision making.

\section{References}

Abdullah, S. N., Ku Ismail, K. N. I., \& Nachum, L. (2016). Does women on boards create value? The impact of societal perceptions and corporate governance in emerging markets. Strategic Management Journal, 37(3), 466-476. https://doi.org/10.1002/smj.2352

Adams, R. B., Hermalin, B. E., \& Weisbach, M. S. (2008). The role of boards of directors in corporate governance: A conceptual framework and survey. Fisher College of Business. https://doi.org/10.3386/w14486

Adams, R. B., \& Ferreira, D. (2007). Gender diversity in the boardroom. European Corporate Governance Institute - Finance Working Paper, 57.

Adams, R. B., \& Ferreira, D. (2009). Women in the Boardroom and their Impact on Governance and $\begin{array}{lllll}\text { Performance. Journal of } & \text { Financial }\end{array}$ https://doi.org/10.1016/j.jfineco.2008.10.007

Ajina, A., \& Lakhal, F. (2010). Ownership structure and stock market liquidity in France. Bankers, Markets and Investors, 104, 44-51.

Arfken, D. E., Bellar, S. L., \& Helms M. M. (2004). The Ultimate Glass Ceiling Revisited: The Presence of Women on Corporate Boards. Journal of Business Ethics, 50(2), 177-186. https://doi.org/10.1023/B:BUSI.0000022125.95758.98

Balasubramanian, N. (2013). Gender Equality, Inclusivity and Corporate Governance in India. Journal of Human Values, 19(1), 15-28. https://doi.org/10.1177/0971685812470327

Baranchuk, N., \& Dybvig, P. (2009). Consensus in diverse corporate boards. Review of Financial Studies, 22, 715-747. https://doi.org/10.1093/rfs/hhn052

Bart, C., \& McQueen, G. (2013). Why women make better directors? International Journal of Business 
Governance and Ethics, 8, 93-99. https://doi.org/10.1504/IJBGE.2013.052743

Bear, S., Rahman, N., \& Post, C. (2010). The impact of board diversity and gender composition on corporate social responsibility and firm reputation. Journal of Business Ethics, 97, 207-221. https://doi.org/10.1007/s10551-010-0505-2

Beatty, R. P., \& Zajac, E. J. (1987). CEO change and firm performance in large corporations: succession effects and manager effects. Strategic Management Journal, 8(4), 305-317. https://doi.org/10.1002/smj.4250080402

Bernardi, R. A., Bean, D. F., \& Weippert, K. M. (2002). Signaling gender diversity through annual report pictures: A research note on image management. Accounting, Auditing \& Accountability Journal, 15(4), 609-616. https://doi.org/10.1108/09513570210441440

Boehmer, E., Musumeci, J., \& Poulsen, A. (1991). Event study methodology under conditions of event-induced variance. Journal of Financial Economics, 30(2), 253-272. https://doi.org/10.1016/0304-405X(91)90032-F

Bonnier, K. A., \& Bruner, R. F. (1988). An analysis of stock price reaction to management change in distressed firms. Journal of Accounting and Economics, 11(1), 95-106. https://doi.org/10.1016/0165-4101(89)90015-3

Boulouta, I. (2013). Hidden Connections: The Link between board gender diversity and corporate social performance. Journal of Business Ethics, 113, 185-197. https://doi.org/10.1007/s10551-012-1293-7

Bradshaw, P., \& Wicks, D. (2000). The experiences of white women on corporate boards in Canada: compliance and non-compliance to hegemonic masculinity. In R. J. Burke, \& M. C. Mattis (Eds.), Women on Corporate Boards of Directors. The Netherlands: Kluwer Academic Publishers. https://doi.org/10.1007/978-90-481-3401-4_14

Brammer, S., Millington, A., \& Pavelin, S. (2009). Corporate reputation and women on the board. British Journal of Management, 20(1), 17-29. https://doi.org/10.1111/j.1467-8551.2008.00600.x

Brown, S. J., \& Warner, J. B. (1980). Measuring security price performance. Journal of Financial Economics, 8(3), 205-258. https://doi.org/10.1016/0304-405X(80)90002-1

Brown, S. J., \& Warner, J. B. (1985). Using daily stock returns: the case of event studies. Journal of Financial Economics, 14(1), 3-31. https://doi.org/10.1016/0304-405X(85)90042-X

Brown, D. A. H., Brown, D. L., \& Anastasopoulos, V. (2002). Women on Boards: Not just the Right Thing . . But the "Bright" Thing, Report, 341-02: The Conference Board of Canada, Ottawa.

Campbell, K., \& Mínguez-Vera, A. (2008). Gender Diversity in the Boardroom and Firm Financial Performance. Journal of Business Ethics, 83(3), 435-451. https://doi.org/10.1007/s10551-007-9630-y

Campbell, K., \& Minguez-Vera, A. (2010). Female board appointments and firm valuation: Short and long-term effects. Journal of Management \& Governance, 14(1), 37-59. https://doi.org/10.1007/s10997-009-9092-y

Campbell, J. Y., Lo, A. W., \& MacKinlay, A. C. (1997). The econometrics of financial markets 2. Princeton, New Jersey: Princeton University Press.

Carter, D. A., Simkins, B. J., \& Simpson, W. G. (2003). Corporate Governance, Board Diversity and Firm Value. Financial Review, 38(1), 33-53. https://doi.org/10.1111/1540-6288.00034

Carter, D. A., D'Souza, F., Simkins, B. J., \& Simpson, W. G. (2010). The Gender and Ethnic Diversity of US Boards and Board Committees and Firm Financial Performance. Corporate Governance: An International Review, 18(5), 396-414. https://doi.org/10.1111/j.1467-8683.2010.00809.x

Catalyst (2004). The bottom line: connecting corporate performance and gender diversity. New York, NY: Catalyst.

Catalyst (2007). The bottom line: corporate performance and women's representation on boards. New York, NY: Catalyst.

Charitou, M., Patis, A., \& Vlittis, A. (2010). The market reaction to the appointment of an outside CEO: An empirical investigation. Journal of Economics and International Finance, 2(11), 272-277.

Clarkson, M. B. E. (1995). A stakeholder framework for analyzing and evaluating corporate social performance. Academy of Management Review, 20, 65-91.

Consob (2016). Report on corporate governance of Italian listed companies. Statistics and analyses, Rome: Consob. 
Consob (2017). Report on corporate governance of Italian listed companies. Statistics and analyses, Rome: Consob.

Corrado, C. (1989). A nonparametric test for abnormal security-price performance in event studies. Journal of Financial Economics, 23(2), 385-395. https://doi.org/10.1016/0304-405X(89)90064-0

Daily, C. M., Certo, S. T., \& Dalton D. R. (1999). A Decade of Corporate Women: Some Progress in the Boardroom, None in the Executive Suite. Strategic Management Journal, 20(1), 93-99. https://doi.org/10.1002/(SICI)1097-0266(199901)20:1<93::AID-SMJ18>3.0.CO;2-7

Dale-Olsen, H., Schøne, P., \& Verner, M. (2013). Diversity among Norwegian Boards of Directors: Does a Quota for Women Improve Firm Performance? Feminist Economics, 19(4), 110-135. https://doi.org/10.1080/13545701.2013.830188

Davidson, W. N., Nemec, C., Worrell, D. L., \& Lin, J. (2002). Industrial origin of CEOs in outside succession: Board preference and stockholder reaction. Journal of Management \& Governance, 6, 295-321. https://doi.org/10.1023/A:1021242931026

Denis, D. J., \& Diane, K. D. (1995). Performance changes following top management dismissals. The Journal of Finance, 50(4), 1029-1057. https://doi.org/10.1111/j.1540-6261.1995.tb04049.x

Diaz-Garcia, C., Gonzalez-Moreno, A., \& Saez-Martinez, F. (2013). Gender diversity within R\&D teams: Its impact on radicalness of innovation. Innovations, Management, Policy \& Practice, 15, 149-160. https://doi.org/10.5172/impp.2013.15.2.149

Ding, D. K., \& Charoenwong, C. (2013). Stock market reaction when listed companies in Singapore appoint female directors, International Journal of Management, 30(1), 285-300.

Dobbin, F., \& Jung, J. (2011). Corporate board gender diversity and stock performance: The competence gap or institutional investor bias?. North Carolina Law Review, 89(3), 809-838.

Donaldson, T., \& Preston, E. (1995). The stakeholder theory of the corporation: concepts, evidence, and implications. Academy of Management Review, 20(1), 65-91.

Dunn, P. (2012). Breaking the boardroom gender barrier: the human capital of female corporate directors. Journal of Management \& Governance, 16(4), 557-570. https://doi.org/10.1007/s10997-010-9161-2

Erhardt, N. L., Werbel, J. D., \& Shrader, C. B. (2003). Board of Director Diversity and Firm Financial Performance. Corporate Governance: An International Review, 11, 102-110. https://doi.org/10.1111/1467-8683.00011

Fama, E.F. (1970). Multiperiod consumption-investment decisions. The American Economic Review, 60(1), $163-174$

Fama, E.F. (1980). Agency Problems and the Theory of the Firm. The Journal of Political Economy, 88(2, Apr), 288-307. https://doi.org/10.1086/260866

Farrell, K. A., \& Hersch, P. L. (2005). Additions to corporate boards: The effect of gender. Journal of Corporate Finance, 11(1/2), 85-106. https://doi.org/10.1016/j.jcorpfin.2003.12.001

Fernandez-Feijoo, B., Romero, S., \& Ruiz, S. (2012). Does board gender composition affect corporate social responsibility reporting?. International Journal of Business and Social Science, 3(1), 31-38.

Ferreira, D. (2010). Board diversity. In R. Anderson, \& H.K. Baker (Eds.), Corporate governance. Hoboken, NJ: Wiley \& Sons. https://doi.org/10.1002/9781118258439.ch12

Francoeur, C., Labelle, R., \& Sinclair-Desgagne, B. (2008). Gender Diversity in Corporate Governance and Top Management, Journal of Business Ethics, 81(1), 83-95. https://doi.org/10.1007/s10551-007-9482-5

Fredericks, E. (2014). First Female Directors: Market Response. Honors Projects, Paper 313. http://scholarworks.gvsu.edu/honorsprojects/313

Freeman, R. E. (1984). Strategic management: A stakeholder approach, New York: Basic Books.

Friedman, S, \& Singh, H. (1989). CEO succession and stockholder reaction: the influence of organizational context and event content. Academy of Management Journal, 32, 718-744. https://doi.org/10.2307/256566

Galia, F., \& Zenou, E. (2012). Board composition and forms of innovation: does diversity make a difference? European Journal of International Management, 6(6), 630-650. https://doi.org/10.1504/EJIM.2012.050425

Gilbert, J. A., Stead, B. A., \& Ivancevich, J. M. (1999). Diversity management: A new organizational paradigm. 
Journal of Business Ethics, 21(1), 61-76. https://doi.org/10.1023/A:1005907602028

Gul, F. A., Min, C., \& Srinihdi, B. (2010). Gender Diversity on US Corporate Boards and Cost of Capital. American Accounting Association Annual Meeting and Conference on Teaching and Learning in Accounting, San Francisco. http://www.uic.edu/cba/accounting/Documents/srinidhi-paper-Faq.pdf

Haslam, S. A., Ryan, M.K., Kulich, C., Trojanowski, G., \& Atkins, C. (2010). Investing with prejudice: The relationship between women's presence on company boards and objective and subjective measures of company performance. British Journal of Management, 21(2), 484-497.

Haynes, K. T., \& Hillman, A. (2010). The effect of board capital and CEO power on strategic change. Strategic Management Journal, 31, 1145-1163. https://doi.org/10.1002/smj.859

Hillman, A. J., Cannella, A. A., \& Paetzold, R. L. (2000). The resource dependency role of corporate directors: Strategic adoption of board composition in response to environmental change. Journal of Management Studies, 37, 235-255. https://doi.org/10.1111/1467-6486.00179

Hillman, A. J., Keim, G. D., \& Luce, R. A. (2001). Board composition and stakeholder performance: Do stakeholder directors make a difference?. Business \& Society, 40, 295-314. https://doi.org/10.1177/000765030104000304

Hillman, A. J., Shropshire, C., \& Cannella, A. A. Jr. (2007). Organizational predictors of women on corporate boards. Academy of Management Journal, 50(4), 941-952. https://doi.org/10.5465/AMJ.2007.26279222

Hoogendoorn, S., Oosterbeek, H., \& Van Praag, M. (2013). The Impact of Gender Diversity on the Performance of Business Teams: Evidence from a Field Experiment. Management Science, 59(7), 1514-1528. https://doi.org/10.1287/mnsc.1120.1674

Huse, M. (2007). Boards, governance and value creation: the human side of corporate governance. Cambridge: Cambridge University Press. https://doi.org/10.1017/CBO9780511611070

Huse, M., \& Solberg, A. G. (2006). Gender-related boardroom dynamics: How Scandinavian women make and can make contributions on corporate boards. Women in Management Review, 21(2), 113-130. https://doi.org/10.1108/09649420610650693

Huse, M., Hoskisson, R., Zattoni, A., \& Viganò, R. (2011). New perspectives on board research: Changing the research agenda, Journal of Management and Governance, 15(1), 5-28. https://doi.org/10.1007/s10997-009-9122-9

Jensen, M. C., \& Meckling, W. H. (1976). Theory of the firm: Managerial behavior, agency costs and ownership structure. Journal of Financial Economics, 3, 305-360. https://doi.org/10.1016/0304-405X(76)90026-X

Kang, E. (2008). Director interlocks and spillover effects of reputational penalties from financial reporting fraud. Academy of Management Journal, 51(3), 537-555. https://doi.org/10.5465/AMJ.2008.32626007

Kang, E., Din, D. K., \& Charoenwong, C. (2010). Investor reaction to women directors. Journal of Business Research, 63(8), 888-894. https://doi.org/10.1016/j.jbusres.2009.06.008

Kanter, R. M. (1977). Men and women of the corporation, New York: Basic Books.

Karmani, M., Ajina, A., \& Boussaada, R. (2015). An investigation of the relation between corporate governance and liquidity: empirical evidence from France. The Journal of Applied Business Research, 31(2), 631-646. https://doi.org/10.19030/jabr.v31i2.9118

Kesner, I. F. (1988). Directors' characteristics and committee membership: An investigation of type, occupation, tenure, and gender. Academy of Management Journal, 31, 66-84. https://doi.org/10.2307/256498

Ku Ismail, N. I. K., \& Manaf, K. B. A. (2016). Market reactions to the appointment of women to the boards of Malaysian firms. Journal of Multinational Financial Management, 36, 75-88. https://doi.org/10.1016/j.mulfin.2016.04.004

Lee, P. M., \& James, E. H. J. (2007). She'-e-os: gender effects and investor reactions to the announcements of top executive appointments. Strategic Management Journal, 28, 227-241. https://doi.org/10.1002/smj.575

Lubatkin, M., \& Shrieves, R. E. (1986). Towards reconciliation of market performance measures to strategic management research. Academy of Management Review, 11(3), 497-512.

Lückerath-Rovers, M. (2013). Women on boards and firm performance. Journal of Management and Governance, 17, 491-508. https://doi.org/10.1007/s10997-011-9186-1 
Matsa, D. A., \& Miller, A. R. (2013). A Female Style in Corporate Leadership? Evidence from Quotas. American Economic Journal: Applied Economics, July, 5(3), 136-169. https://doi.org/10.1257/app.5.3.136

Miller, T., \& Triana, M. C. (2009). Demographic diversity in the boardroom: Mediators of the board diversity-firm performance relationship. Journal of Management Studies, 46(5), 755-786. https://doi.org/10.1111/j.1467-6486.2009.00839.x

Nguyen, H., \& Faff, R. (2006). Impact of board size and board diversity on firm value: Australian evidence. Corporate Ownership and Control, 4(2), 24-32.

Nielsen, S., \& Huse, M. (2010). The contribution of women on boards of directors: Going beyond the surface. Corporate Governance: An International Review, 18(2), 136-148. https://doi.org/10.1111/j.1467-8683.2010.00784.x

Ntim, G. C. (2015). Board diversity and organizational valuation: unravelling the effects and gender. Journal of Management and Governance, 19, 167-195. https://doi.org/10.1007/s10997-013-9283-4

Olson, S. F., \& Currie, H. M. (1992). Female Entrepreneurs: Personal Value Systems and Business Strategies in a Male-Dominated Industry. Journal of Small Business Management, 30(1), 49-58.

O'Neal, D., \& Thomas H. (1986). Developing the strategic board. Long Range Plan, 29(3), 314-327. https://doi.org/10.1016/0024-6301(96)00027-1

Østergaard, C. R., Timmermans, B., \& Kristinsson, K. (2011). Does a different view create something new? The effect of employee diversity on innovation. Research Policy, 40(3), 500-509. https://doi.org/10.1016/j.respol.2010.11.004

Pastore, P., \& Tommaso, S. (2016). Women on Corporate Boards. The case of 'gender quotas' in Italy. Corporate Ownership and Control, 13(4), Summer 2016, 132-155. https://doi.org/10.22495/cocv13i4p13

Patell, J. M. (1976). Corporate forecasts of earning per share and stock price behavior: empirical tests. Journal of Accounting Research, 14(2), 246-276. https://doi.org/10.2307/2490543

Pfeffer, J. (1973). Size, composition, and function of hospital boards of directors: A study of organization-environmental linkage. Administrative Science Quarterly, 18, 349-364. https://doi.org/10.2307/2391668

Pfeffer, J., \& Salancik, G. R. (1978). The external control of organizations: A resource dependence perspective. New York: Harper \& Row.

Rose, C. (2007). Does female board representation influence firm performance? The Danish evidence. Corporate Governance: An International Review, 15(2), 404-413. https://doi.org/10.1111/j.1467-8683.2007.00570.x

Rosener, J. B. (1997). America's Competitive Secret. Women Managers. Oxford: Oxford University Press.

Sanders, W. M., \& Boivie, S. (2004). Sorting things out: Valuation of new firms in uncertain markets. Strategic Management Journal, 25(2), 167-186. https://doi.org/10.1002/smj.370

Shrader, C., Blackburn, V., \& Iles, P. (1997). Women in management and firm financial performance: An exploratory study. Journal of Managerial Issues, 9, 355-372.

Siciliano, J., (1996). The Relationship of Board Member Diversity to Organizational Performance. Journal of Business Ethics, 15(12), 1313-1320. https://doi.org/10.1007/BF00411816

Singh, V., Vinnicombe, S., \& Johnson P. (2001). Women Directors on Top UK Boards. Corporate Governance: An International Review, 9(3), 206-216. https://doi.org/10.1111/1467-8683.00248

Singh, V., Terjesen, S., \& Vinnicombe, S. (2008). Newly appointed directors in the boardroom: How do women and men differ?. European Management Journal, 26(1), 48-58. https://doi.org/10.1016/j.emj.2007.10.002

Smith, N., Smith, V., \& Verner M. (2006). Do women in top management affect firm performance? A panel study of 2500 Danish firms. International Journal of Productivity and Performance Management, 55, 569-593. https://doi.org/10.1108/17410400610702160

Solakoglu, M. (2013). The role of gender diversity on firm performance: a regression quantile approach. Applied Economics Letters, 20(17), 1562-1566. https://doi.org/10.1080/13504851.2013.829184

Sougné, D., Ajina, A., \& Lakhal, F. (2015). Corporate Disclosures, Information Asymmetry and Stock-Market Liquidity in France. Journal of Applied Business Research, 31(4), 1223-1237. https://doi.org/10.19030/jabr.v31i4.9297 
Stephenson, C. (2004). Leveraging diversity to maximum advantage: the business case for appointing more women to boards. Ivey Business Journal, 69(1), 1-5.

Terjesen, S., Sealy, R., \& Singh, V. (2009). Women directors on corporate boards: A review and research agenda. Corporate Governance: An International Review, 17(3), 320-337. https://doi.org/10.1111/j.1467-8683.2009.00742.x

Triana, M. C., Miller, T. L., \& Trezebiatowski, T. M. (2014). The double-edged nature of board gender diversity: Diversity, firm performance, and the power of women directors as predictors of strategic change. Organization Science, 25(2), 609-632. https://doi.org/10.1287/orsc.2013.0842

Ujunwa, A., Okoyenzu, C., \& Nwakoby, I. (2012). Corporate board diversity and firm performance: Evidence from Nigeria. Review of International Comparative Management, 13, 605-620. https://doi.org/10.22495/cocv9i2c1art6

Van der Walt, N., \& Ingley, C. (2003). Board dynamics and the influence of professional background, gender and ethnic diversity of directors. Corporate Governance: An International Review, 11(3), 218-234. https://doi.org/10.1111/1467-8683.00320

Van der Walt, N., Ingley, C., Shergill, G.S., \& Townsend, A. (2006). Board configuration: Are diverse boards better boards?. Corporate Governance: An International Review, 6, 129-147. https://doi.org/10.1108/14720700610655141

Waddock, S., \& Graves, S. (1997). The Corporate Social Performance-Financial Performance Link. Strategic $\begin{array}{lll}\text { Management Journal, } & \text { 18(4), } & 303-319 .\end{array}$ https://doi.org/10.1002/(SICI)1097-0266(199704)18:4<303::AID-SMJ869>3.0.CO;2-G

Walsh, J. P., \& Seward, J. K. (1990). On the efficiency of internal and external corporate control mechanisms. Academy Management Review, 15(3), 421-458.

Warner, J. B., Watts, R. L., \& Wruck, K. H. (1988). Stock prices and top management changes. Journal of financial Economics, 20, 461-492. https://doi.org/10.1016/0304-405X(88)90054-2

Watson, W. E., Kumar, K., \& Michaelsen, L. K. (1993). Cultural diversity's impact on interaction process and performance: comparing homogeneous and diverse task groups. Academy Management Journal, 36(3), 590-602. https://doi.org/10.2307/256593

Westphal, J. D. (1999). Collaboration in the boardroom: Behavioral and performance consequences of CEO-board social ties. Academy Management Journal, 42(1), 7-24. https://doi.org/10.2307/256871

Westphal, J. D., \& Bednar, M. K. (2005). Pluralistic ignorance in corporate boards and firms' strategic persistence in response to low firm performance. Administrative Science Quarterly, 50, 262-298. https://doi.org/10.2189/asqu.2005.50.2.262

Westphal, J. D., \& Milton, L. P. (2000). How experience and network ties affect the influence of demographic minorities on corporate boards. Administrative Science Quarterly, 45(2), 366-398. https://doi.org/10.2307/2667075

Worrell, D. L., \& Davidson W. N. (1987). The effect of CEO succession on stockholder wealth in large firms following the death of the predecessor. Journal of Management, 13(3), 509-515. https://doi.org/10.1177/014920638701300307

Yang, Y., \& Konrad, A. M. (2011). Understanding diversity management practices: Implications of institutional theory and resource-based theory. Group and Organization Management, 36, 6-38. https://doi.org/10.1177/1059601110390997

Zahra, S. A., \& Pearce, J. A. (1989). Boards of directors and corporate financial performance: A review and integrative model. Journal of management, 15(2), 291-334. https://doi.org/10.1177/014920638901500208

Zaltman, G. (1997). Rethinking market research: putting people back. Journal of Marketing Research, 34(November), 424-437. https://doi.org/10.2307/3151962

\section{Notes}

Note 1. However, some researches (Rose, 2007; Baranchuk \& Dybvig, 2009; Ferreira, 2010) have pointed out the possible negative effects of diversity. A higher percentage of women on boards generates longer board meetings to share different points of view and resolve disputes and this has a negative impact on operative 
performance of the board and on the monitoring results. The heterogeneity of interests represented within the board may increase the conflict, the difficulty of communication and the possible emergence of factions within the group which can lessen the board cohesion and negatively affect companies' performance (Dobbin \& Jung, 2011, p. 816). Moreover, Balasusbramanian (2013, p. 21) argued that a "constructive dissonance" may be more productive than a contrived cohesion.

Note 2. On the internal side, women on boards signals that a company values the success of its women and appoints them at the highest levels, protecting itself from claims of discrimination. Women appointed to corporate boards play a direct role in improving outcomes for other women within the organization: female board members represent career opportunities for potential female employees and for women who are working within the firms (female directors become their role models), inspire women employees to senior management roles and often engage in networking and mentoring of women through corporate networks (Terjesen et al., 2009).

Note 3. For example, Carter et al. (2003) found a positive and significant association between companies with women directors and Tobin's Q in a sample of Fortune 1000 companies (in 1997). Similarly, Singh et al. (2001), who examine FTSE 100 companies in 1999-2000 and Nguyen and Faff (2006, who examine women directors in Australian companies) found that the participation of women on boards increases corporate value. Erhardt et al. (2003) found evidence of a positive and significant relation between the board diversity (gender and ethnic diversity) and the return on assets as well as the return on investment in 127 large U.S. companies.

Note 4. For instance, Shrader et al. (1997) found negative, although insignificant, associations between women directorship and several accounting measures of performance for large U.S. companies. Similarly, Rose (2007) found no significant association between Tobin's Q and companies with women directors in Danish firms.

Note 5. Their data consist of 127 firms listed on Bursa Malaysia that appoint women directors over the period 1999-2011 and, by measuring the abnormal returns surrounding the appointment of women directors from day -10 to day 10, find that investors welcome the appointment of women directors (as they understand their potential for improving firm performance) and as such they react favorably to women who are prominent, young, have no international exposure, and have no family relationship with any other director.

\section{Copyrights}

Copyright for this article is retained by the author(s), with first publication rights granted to the journal.

This is an open-access article distributed under the terms and conditions of the Creative Commons Attribution license (http://creativecommons.org/licenses/by/4.0/). 